\title{
CANDIDEMIA IN A BRAZILIAN TERTIARY CARE HOSPITAL: SPECIES DISTRIBUTION AND ANTIFUNGAL SUSCEPTIBILITY PATTERNS
}

\begin{abstract}
SUMMARY
Recent studies have shown differences in the epidemiology of invasive infections caused by Candida species worldwide. In the period comprising August 2002 to August 2003, we performed a study in Santa Casa Complexo Hospitalar, Brazil, to determine Candida species distribution associated with candidemia and their antifungal susceptibility profiles to amphotericin $\mathrm{B}$, fluconazole and itraconazole. Antifungal susceptibility was tested according to the broth microdilution method described in the NCCLS (M27A2 method). Only one sample from each patient was analyzed (the first isolate). Most of the episodes had been caused by species other than C. albicans (51.6\%), including C. parapsilosis (25.8\%), C. tropicalis (13.3\%), C. glabrata (3.3\%), C. krusei (1.7\%), and others (7.5\%). Dose-dependent susceptibility to itraconazole was observed in $14.2 \%$ of strains, and dose-dependent susceptibility to fluconazole was found in $1.6 \%$. Antifungal resistance was not found, probably related to low use of fluconazole. Further epidemiological surveillance is needed.
\end{abstract}

KEYWORDS: Candidemia; Candida species; Antifungal resistance; Susceptibility tests.

\section{INTRODUCTION}

The term candidemia indicates the presence of Candida species in the blood. With the growing number of immunodepressed patients, antibiotic and antifungal use, epidemiology of candidemia has changed in recent years, with emergence of species with reduced susceptibility to antifungal agents $^{5}$. Studies performed in different countries, however, have shown different susceptibility patterns ${ }^{2}$, reinforcing the need of further research. In this study, we analyze the Candida species causing candidemia and their antifungal susceptibility patterns in a large Brazilian hospital.

\section{MATERIAL AND METHODS}

This transversal study included all bloodstream isolates of Candida spp. collected from patients admitted at Santa Casa Complexo Hospitalar, a tertiary care hospital with 1200 beds, from August 2002 to August 2003. To avoid the inclusion of several samples from the same patient, which should bias Candida species distribution, just one sample from each patient was analyzed (the first isolate). Germ tubes were performed, and negative strains were identified through kit ID 32C (BioMérieux SA, France).

Antifungal susceptibility was tested according to the broth microdilution method described in the National Committee for Clinical Laboratory Standards (M27-A2) ${ }^{9}$. In accordance to this protocol, the following antifungal drugs were tested: amphotericin B (Sigma Chemical Corporation, USA), fluconazole, (Pfizer Inc., USA) and itraconazole (Janssen Pharmaceutica, USA). Broth microdilution testing was performed in RPMI-1640 with L-glutamine, without bicarbonate (Gibco Invitrogen Corporation, USA), buffered with MOPS at $\mathrm{pH}$ 7.0. The plates were incubated at $35^{\circ} \mathrm{C}$ for 48 hours, visually read, and then corroborated through an ELISA reader. The minimum inhibitory concentration (MIC) for amphotericin B was defined as the lowest concentration that showed reduction in the turbidity. The MIC for itraconazole and fluconazole was defined as the concentration that showed prominent reduction in the turbidity when compared to a positive control.

Strain susceptibility to fluconazole and itraconazole were classified as susceptible (MIC $\leq 8 \mu \mathrm{g} / \mathrm{mL}$ and MIC $\leq 0.125 \mu \mathrm{g} / \mathrm{mL}$ ), susceptibledose dependent (MIC $16-32 \mu \mathrm{g} / \mathrm{mL}$ and MIC $0.25-0.5 \mu \mathrm{g} / \mathrm{mL}$ ) and resistant $\left(\mathrm{MIC}>32 \mu \mathrm{g} / \mathrm{mL}\right.$ and $\mathrm{MIC}>0.5 \mu \mathrm{g} / \mathrm{mL}$, respectively) ${ }^{9}$. Although there are no established breakpoints for amphotericin $\mathrm{B}$, most susceptible strains show $\mathrm{MIC} \leq 1 \mu \mathrm{g} / \mathrm{mL}$, and that concentration was used to define susceptibility. The control was performed by using standard strains ATCC (American Type Culture Collection): C. krusei $\mathrm{ATCC}^{\circledR}$ 6258 and C. parapsilosis ATCC ${ }^{\circledR} 22019$. The protocol was approved by institutional review board/independent ethics committee, and the authors declare no conflict of interests to write this manuscript. To confirm species and susceptibility, strains were submitted to Department of Pathology, University of Iowa. 


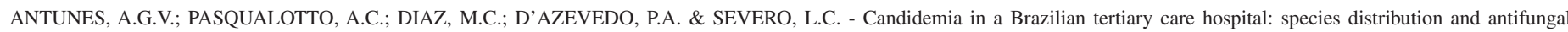
susceptibility patterns. Rev. Inst. Med. trop. S. Paulo, 46(5):239-241, 2004.

\section{RESULTS}

From August 2002 to August 2003, a total of 120 isolates were recovered from patients with candidemia (Table 1). C. albicans $(48.3 \%)$ was the most prevalent one, followed by $C$. parapsilosis $(25.8 \%)$, and C. tropicalis (13.3\%). No resistant strain was found. Dose-dependent susceptibility to itraconazole was observed in isolates of C. krusei (50\%), C. glabrata (25\%), C. parapsilosis (16\%), C. tropicalis (12\%), and C. albicans (7\%). Dose-dependent susceptibility to fluconazole was found only in C. krusei isolates; all strains of C. glabrata were susceptible to fluconazole.

\section{DISCUSSION}

In the present study, we showed that most episodes of candidemia at our institution were caused by species other than C. albicans $(51.6 \%)$. Added, C. glabrata and C. krusei accounted for only $5.0 \%$ of all cases. The distribution of species with reduced susceptibility to azoles, mainly C. glabrata, has shown large variations in different regions of the world. While C. glabrata is the second most prevalent species in the United States $^{2,10,11}$, it is infrequent in South America, contrasting with $C$. parapsilosis and $C$. tropicalis ${ }^{2,6,12}$. In Brazil, $C$. albicans has been the main agent of candidemia (20-50\%), followed by C. parapsilosis (17$35 \%)$, C. tropicalis (12-27\%), and C. guilliermondii $(2-10 \%)^{1,4,7,8} \cdot C$. $k r u s e i$ has been an infrequent cause of candidemia worldwide $(1-2 \%)^{1,10,12}$.

In accordance to our findings, previous studies in South America have shown low rate of antifungal resistance ${ }^{3,6}$. GODOY et al.$^{6}$ found that most Candida spp. isolates were susceptible to all antifungal agents. In a Brazilian study with 200 cases of candidemia, despite the high rate of infections caused by species other than $C$. albicans $(60 \%$, mainly $C$. tropicalis and $C$. parapsilosis), COLOMBO et al. ${ }^{3}$ found that resistance to azoles occurred in only $1.5 \%$ of isolates. In the same study, two isolates of C. krusei and $11 \%$ of isolates of C. glabrata were resistant to fluconazole.

SENTRY studies ${ }^{11}$ showed that there was low resistance to azoles in samples collected in Canada and South America when compared to samples collected in the United States. The less frequent use of fluconazole may explain the low resistance to azoles found in those studies. We have found only two isolates of C. krusei in this study, both of it were susceptible-dose dependent to fluconazole (confirmed by repetition). However, it is known that this species is intrinsically resistant to $\mathrm{it}^{5}$.

Concluding, our study confirmed data from previous studies that demonstrated high prevalence of candidemia in Brazil caused by species other than C. albicans ${ }^{1,4,7}$. Resistance to antifungal agents was not found, and this finding may at least partially be explained by the low use of fluconazole. Epidemiological surveillance, however, is necessary, in order to follow the dynamics of candidemia.

\section{RESUMO}

\section{Candidemia em hospital terciário brasileiro: distribuição das espécies e padrões de susceptibilidade aos antifúngicos}

Estudos realizados em diferentes países têm mostrado diferença na epidemiologia das infecções invasivas por Candida spp. No período de agosto de 2002 a agosto de 2003, foi conduzido estudo na Santa Casa Complexo Hospitalar, Porto Alegre, Brasil, para determinar a distribuição das espécies de Candida associadas a candidemia e o perfil de susceptibilidade das mesmas aos antifúngicos anfotericina B, fluconazol e itraconazol. Os testes de susceptibilidade foram realizados de acordo

Table 1

Species distribution and antifungal susceptibility profile of Candida spp. bloodstream isolates from Santa Casa Complexo Hospitalar ( $\mathrm{n}=120$ ) between August 2002 and August 2003

\begin{tabular}{|c|c|c|c|c|c|c|}
\hline Species & $\mathrm{n}(\%)$ & Antifungal agents & MIC Range $(\mu \mathrm{g} / \mathrm{mL})$ & Suscept. (\%) & Susceptible dose dep. (\%) & Resistant (\%) \\
\hline \multirow{3}{*}{ C. albicans } & 58 & Amphotericin B & $0.25-1.00$ & $100 \%$ & - & - \\
\hline & $(48.3)$ & Fluconazole & $0.12-8.00$ & $100 \%$ & - & - \\
\hline & & Itraconazole & $0.03-0.25$ & $93 \%$ & $7 \%$ & - \\
\hline \multirow[t]{3}{*}{ C. parapsilosis } & 31 & Amphotericin B & $0.12-1.00$ & $100 \%$ & - & - \\
\hline & $(25.8)$ & Fluconazole & $0.12-2.00$ & $100 \%$ & - & - \\
\hline & & Itraconazole & $0.03-0.50$ & $84 \%$ & $16 \%$ & - \\
\hline \multirow{3}{*}{ C. tropicalis } & 16 & Amphotericin B & $0.5-1.00$ & $100 \%$ & - & - \\
\hline & $(13.3)$ & Fluconazole & $0.12-2.00$ & $100 \%$ & - & - \\
\hline & & Itraconazole & $0.03-0.25$ & $88 \%$ & $12 \%$ & - \\
\hline \multirow{3}{*}{ C. glabrata } & 4 & Amphotericin B & $0.50-1.00$ & $100 \%$ & - & - \\
\hline & $(3.3)$ & Fluconazole & $1.00-8.00$ & $100 \%$ & - & - \\
\hline & & Itraconazole & $0.12-0.25$ & $75 \%$ & $25 \%$ & - \\
\hline \multirow[t]{3}{*}{ C. krusei } & 2 & Amphotericin B & $0.50-1.00$ & $100 \%$ & - & - \\
\hline & $(1.7)$ & Fluconazole & $16.00-16.00$ & - & $100 \%$ & - \\
\hline & & Itraconazole & $0.06-0.50$ & $50 \%$ & $50 \%$ & - \\
\hline \multirow[t]{3}{*}{ Other species $*$} & 9 & Amphotericin B & $0.25-1.00$ & $100 \%$ & - & - \\
\hline & $(7.5)$ & Fluconazole & $0.25-4.00$ & $100 \%$ & - & - \\
\hline & & Itraconazole & $0.03-0.50$ & $56 \%$ & $44 \%$ & - \\
\hline
\end{tabular}

* Other species included C. famata $(\mathrm{n}=2)$, C. sake $(\mathrm{n}=2)$, C. guillermondii $(\mathrm{n}=2)$, C. lusitaniae $(\mathrm{n}=1)$, C. dubliniensis $(\mathrm{n}=1)$, C. lipolytica $(\mathrm{n}=1)$. 
com a metodologia M27-A2 padronizada pelo NCCLS. Foi incluído no estudo o primeiro isolado de hemocultivo de cada paciente. A maioria dos episódios $(51,6 \%)$ ocorreu por espécies outras que C. albicans, incluindo C. parapsilosis (25,8\%), C. tropicalis (13,3\%), C. glabrata $(3,3 \%)$, C. krusei $(1,7 \%)$ e outras espécies $(7,5 \%)$. Não foi encontrada resistência aos antifúngicos testados, possivelmente devido ao baixo consumo de fluconazol na Instituição. Susceptibilidade dose-dependente ao itraconazol ocorreu em 14,2\% e ao fluconazol 1,6\%. Faz-se necessário monitoramento epidemiológico.

\section{ACKNOWLEDGEMENTS}

To Prof. Sydney Hartz Alves, for his help in implementing the methodology M27-A2. To Prof. Michael Pfaller and Richard Hollis, who kindly tested our strains and reviewed this paper. This study was funded by the researchers. Antifungal agents for susceptibility tests were given by pharmaceutical companies (material and methods).

\section{REFERENCES}

1. COLOMBO, A.L.; NUCCI, M.; SALOMÃO, R. et al. - High rate of non-albicans candidemia in Brazilian tertiary care hospitals. Diagn. Microbiol. infect. Dis., 34: 281-286, 1999.

2. COLOMBO, A.L.; PERFECT, J.; DINUBILE, M. et al. - Global distribution and outcomes for Candida species causing invasive candidiasis: results from an international randomized double-blind study of caspofungin versus amphotericin B for the treatment of invasive candidiasis. Europ. J. clin. Microbiol. infect. Dis., 22: 470-474, 2003.

3. COLOMBO, A.L.; NAKAGAWA, Z.; VALDETARO, F. et al. - Susceptibility profile of 200 bloodstream isolates of Candida spp. collected from Brazilian tertiary care hospitals. Med. Mycol., 41: 235-239, 2003.
4. COSTA, S.F.; MARINHO, I.; ARAÚJO, E.A. et al. - Nosocomial fungaemia: a 2-year prospective study. J. Hosp. Infect., 45: 69-72, 2000.

5. EGGIMANN, P.; GARBINO, J. \& PITTET, D. - Epidemiology of Candida species infections in critically ill non-immunosuppressed patients. Lancet infect. Dis., 3: 685-702, 2003.

6. GODOY, P.; TIRABOSCHI, I.N.; SEVERO, L.C. et al. - Species distribution and antifungal susceptibility profile of Candida spp. bloodstream isolates from Latin American Hospitals. Mem. Inst. Oswaldo Cruz, 98: 401-405, 2003.

7. GOLDANI, L.Z. \& MÁRIO, P.S.S. - Candida tropicalis fungemia in a tertiary care hospital. J. Infect., 46: 155-160, 2003.

8. MATSUMOTO, F.E.; GANDRA, R.F.; RUIZ, L.S. et al. - Yeasts isolated from blood and catheter in children from a public hospital of São Paulo, Brazil. Mycopathologia, 154: 63-69, 2001.

9. NATIONAL COMMITTEE FOR CLINICAL LABORATORY STANDARDS - Reference method for broth dilution antifungal susceptibility testing of yeasts; approved standards. Wayne, NCCLS, 2002. (NCCLS document M27-A2).

10. PAPPAS, P.G.; REX, J.H.; LEE, J. et al. - A prospective observational study of candidemia: epidemiology, therapy, and influences on mortality in hospitalized adult and pediatric patients. Clin. infect. Dis., 37: 634-643, 2003.

11. PFALLER, M.A.; JONES, R.N.; DOERN, G.V. et al. - Bloodstream infections due to Candida species: SENTRY antimicrobial surveillance program in North America and Latin America, 1997-1998. Antimicrob. Agents Chemother., 44: 747-751, 2000.

12. PFALLER, M.A.; DIEKEMA, D.J.; JONES, R.N. et al. - International surveillance of bloodstream infections due to Candida species: frequency of occurrence and in vitro susceptibilities to fluconazole, ravuconazole, and voriconazole of isolates collected from 1997 through 1999 in the SENTRY antimicrobial surveillance program. J. clin. Microbiol., 39: 3254-3259, 2001

Received: 1 June 2004

Accepted: 18 August 2004 